\title{
NAAG peptidase inhibitors block cognitive deficit induced by MK-801 and motor activation induced by d-amphetamine in animal models of schizophrenia
}

\author{
RT Olszewski ${ }^{1}$, KJ Janczura ${ }^{1}$, SR Ball, JC Madore, KM Lavin, JC-M Lee, MJ Lee, EK Der, TJ Hark, PR Farago, CP Profaci, \\ T Bzdega and JH Neale
}

The most widely validated animal models of the positive, negative and cognitive symptoms of schizophrenia involve administration of $d$-amphetamine or the open channel NMDA receptor blockers, dizocilpine (MK-801), phencyclidine (PCP) and ketamine. The drug ZJ43 potently inhibits glutamate carboxypeptidase II (GCPII), an enzyme that inactivates the peptide transmitter $\mathrm{N}$-acetylaspartylglutamate (NAAG) and reduces positive and negative behaviors induced by PCP in several of these models. NAAG is an agonist at the metabotropic glutamate receptor 3 (mGluR3). Polymorphisms in this receptor have been associated with expression of schizophrenia. This study aimed to determine whether two different NAAG peptidase inhibitors are effective in dopamine models, whether their efficacy was eliminated in GCPII knockout mice and whether the efficacy of these inhibitors extended to MK-801-induced cognitive deficits as assessed using the novel object recognition test. ZJ43 blocked motor activation when given before or after $d$-amphetamine treatment. (R,S)-2-phosphono-methylpentanedioic acid (2-PMPA), another potent NAAG peptidase inhibitor, also reduced motor activation induced by PCP or $d$-amphetamine. 2-PMPA was not effective in GCPII knockout mice. ZJ43 and 2-PMPA also blocked MK-801-induced deficits in novel object recognition when given before, but not after, the acquisition trial. The group II mGluR antagonist LY341495 blocked the effects of NAAG peptidase inhibition in these studies. 2-PMPA was more potent than ZJ43 in a test of NAAG peptidase inhibition in vivo. By bridging the dopamine and glutamate theories of schizophrenia with two structurally different NAAG peptidase inhibitors and demonstrating their efficacy in blocking MK-801-induced memory deficits, these data advance the concept that NAAG peptidase inhibition represents a potentially novel antipsychotic therapy.

Translational Psychiatry (2012) 2, e145; doi:10.1038/tp.2012.68; published online 31 July 2012

\section{Introduction}

Although antipsychotic drugs are effective in treating positive symptoms of schizophrenia (agitation, psychosis, paranoid delusions and hallucinations), they are less effective in moderating negative symptoms (autism, ambivalence, apathy and social withdrawal) and cognitive deficits, including memory formation, problem solving, sensory gating, illogical joining of thoughts and words. ${ }^{1-5}$ The worldwide personal and societal costs of psychotic disorders support the need to develop new pharmacotherapies, particularly those with mechanisms of action outside of the typical and atypical antipsychotics. Group II metabotropic glutamate receptor (mGluR2 and mGluR3) agonists represent one of these new approaches. ${ }^{6-11}$

Schizophrenia is modeled by two non-exclusive theories based on disordered dopamine- and glutamate-mediated neurotransmission. ${ }^{1,12}$ The glutamate theory evolved from the observation that open channel NMDA ( $N$-methyl-D-aspartate) receptor antagonists (phencyclidine (PCP), ketamine and dizocilpine (MK-801)) induce schizophrenia-like behaviors in humans and animals, while the dopamine theory is based on the clinical efficacy of dopamine (D2) receptor antagonists and the behaviors induced by dopamine-releasing drugs, including $d$-amphetamine. Responses of animals to treatment with $d$-amphetamine or these NMDA antagonists, including motor activation, have been widely validated as models for preclinical assessment of antipsychotic drugs. ${ }^{1,13-25}$

$\mathrm{N}$-acetylaspartylglutamate (NAAG) is the third most prevalent and widely distributed transmitter in the mammalian nervous system. ${ }^{26}$ This peptide cotransmitter activates a group II mGluR3 ${ }^{27}$ Inhibitors of the enzymes that inactivate NAAG, ZJ43 and (R,S)-2-phosphono-methylpentanedioic acid (2-PMPA) elevate extracellular levels of the peptide and lead to increased activation of mGluR3 ${ }^{28-31}$ ZJ43 reduces positive and negative behaviors induced by PCP in animal models of schizophrenia. ${ }^{29,32,33}$ Similarly, heterotropic group II mGluR2/3 agonists moderate the effects of amphetamine, PCP and MK-801 in animal models of schizophrenia $^{8,16,18,21,23,25,34-41}$ and are in clinical trials. ${ }^{42,43}$ In contrast

Department of Biology, Georgetown University, Washington, DC, USA

Correspondence: Professor JH Neale, Department of Biology, Georgetown University, 37th and O Sts., N.W., Washington, DC 20057-1225, USA.

E-mail: nealej@georgetown.edu

${ }^{1}$ These are co-first authors.

Keywords: cognition; d-amphetamine; NAAG; N-acetylaspartylglutamate; PCP; schizophrenia

Received 26 January 2012; revised 27 April 2012; accepted 31 May 2012 
to NAAG activation of mGluR3, knockout studies indicate that the effects of these agonists in PCP studies are mediated by mGluR2, perhaps owing to their modestly higher level of activation of this receptor in vitro. ${ }^{23,25,36,44}$ Similarly, positive allosteric modulators of mGluR2 are effective in PCP models. ${ }^{6}$

We previously reported that the NAAG peptidase inhibitor ZJ43 is effective in reducing positive (motor activation and stereotypic movements) and negative (social withdrawal) behaviors induced in rats and mice based on the PCP/ glutamate model of schizophrenia. ${ }^{29,32,33}$ A substantial body of data support the conclusion that these actions result from NAAG's activation of mGluR3. ${ }^{26-29,45,46}$ Although limited to a single peptidase inhibitor, these reports supported the hypothesis that NAAG peptidase inhibition might represent a novel therapeutic approach to treating schizophrenia based on the glutamate theory of this disorder. The present research aimed to more rigorously extend this hypothesis in animal models based on both the dopamine and glutamate theories of the disorder, to determine whether similar effects are obtained with a structurally different NAAG peptidase inhibitor, to confirm that the NAAG peptidase, glutamate carboxypeptidase II (GCPII), mediates the effects of these drugs and to determine whether the efficacy of NAAG peptidase inhibition extends to memory dysfunction induced by MK-801 in the novel object recognition test. ${ }^{17}$ Although the absence of drugs specifically approved for treatment of the memory deficits in patients with schizophrenia precludes confirming the predictive efficacy of this or any animal models of schizophrenia-like memory deficits, this test is widely used in preclinical assessments of novel antipsychotic drugs and has been 'validated' inasmuch as currently approved antipsychotics moderate cognitive deficits in animal models of this disorder as measured by object recognition. ${ }^{13,15,17-19,22,24,37,47-49}$

\section{Materials and methods}

Animals. The experimental protocols used in this research were approved by the Georgetown University Animal Care and Use Committee consistent with guidelines of the US National Institutes of Health. Adult male C57BL/6NCr (C57BL) mice (National Cancer Institute, Frederick Research Center, USA), DBA/2 mice (Taconic Farms, MD) and male Sprague-Dawley (SD) rats (initial weight $200 \mathrm{~g}$; Taconic, Germantown, MD) were housed in groups of five (mice) or two (rats). GCPII knockout mice ${ }^{50}$ were provided by Warren Heston, rederived by in vitro fertilization in Jackson Laboratory (Bar Harbor, ME) and 10 pathogen-free mice (four heterozygous females and six males,) were transferred to Georgetown where a colony was established. The knockout mice used in this study were backcrossed at least 10 times to C57BL mice. Food and water were available ad libitium. Animals were maintained on a $12: 12 \mathrm{~h}$ light-dark cycle. Testing was performed between 1000 hours and 1600 hours in the light cycle. Animals were weighed before drug administration to permit accurate dosing.

Drugs. $N$-[[[(1S)-1-Carboxy-3-methylbutyl]amino]carbonyl]L-glutamic acid (ZJ43) (ref. 51) and ZJ44 were synthesized by Alan Kozikowski as previously described. ${ }^{32}$ ZJ44 is the same as ZJ43 except it is lacking a single $\mathrm{CH}_{2}$ group on the one side chain of ZJ43 that lacks a carboxyl group ( $N$ - $[[[(1 S)$ 1-Carboxy-3-methylpropyl]amino]carbonyl]-L-glutamic acid). When tested against membranes from $\mathrm{CHO}$ (Chinese hamster ovary) cells stably transfected with human GCPII, 2-PMPA, ZJ43 and ZJ44 had $K_{\mathrm{i}}$ values of $1.4 \pm 0.09 \mathrm{nM}$, $0.79 \pm 0.06 \mathrm{nM}$ and $39.4 \pm 2.9 \mathrm{nM}$ respectively (Wroblewski, Kozikowski and Neale, unpublished, methods described in ref. 52). 2-PMPA ${ }^{30,53,54}$ and LY341495 were from Tocris Cookson (Bristol, UK). LY341495 is a selective group II mGluR antagonist. ${ }^{55}$ PCP and MK-801 ([+ ]-5-methyl-10, 11-dihydro-5H-dibenzo[a,d]cyclohepten-5, 10-imine maleate) were from Sigma Aldrich (St Louis, MO). Risperidone, (3-[2[4-(6-Fluoro-1,2-benzisoxazol-3-yl)-1-piperidinyl]-ethyl]-6,7, 8,9-tetrahydro-2-methyl-4H-pyrido[1,2-a]pyrimidin-4-one; molecular weight $=410.49$ ), was from the $\mathrm{NIMH}$ Chemical Synthesis and Drug Supply Program (http://nimhrepository.rti.org). All compounds were dissolved in saline and were delivered by intraperitoneal (i.p.) injection. Anesthetics ketamine $\mathrm{HCl}$ and xylazine $\mathrm{HCl}$ (Sigma Aldrich, St Louis, MO) were administered by at $1 \mathrm{ml} \mathrm{kg}^{-1}$ i.p. injection of a mixture containing $12 \mathrm{mg}$ xylazine $\mathrm{HCl}$ and $80 \mathrm{mg}$ ketamine $\mathrm{HCl}$ per $\mathrm{ml}$. The final $\left[{ }^{3} \mathrm{H}\right]$-NAAG (Perkin Elmer, Waltham, MA) solution was prepared as $79 \mu \mathrm{l}$ of artificial cerebrospinal fluid containing (in $\mathrm{mm}$ ) $126 \mathrm{NaCl}, 26$ $\mathrm{NaHCO}_{3}, 2.5 \mathrm{KCl}, 1.25 \mathrm{NaHPO}_{4}, 2 \mathrm{MgCl}_{2}, 2 \mathrm{CaCl}_{2}$ and 10 glucose, together with $20 \mu \mathrm{l}$ of $1 \mu \mathrm{M}$ solution of NAAG and $1 \mu \mathrm{l}$ of $\left[{ }^{3} \mathrm{H}\right]-N A A G\left(100000 \mathrm{dpm}, 49.6 \mathrm{Ci} \mathrm{mmol}^{-1}\right.$, approximately $1 \mathrm{pmol})$.

Motor activation in open field. Adult male $\mathrm{C} 57 \mathrm{BL}$ and DBA/2 mice, 25-30 g in weight, were placed individually in eight MED ASSOCIATES (St Albans, VT) ENV-515 open field chambers $(43 \times 43 \mathrm{~cm})$ with evenly spaced pairs of infrared beams and detectors. After a 30-min habituation interval, each animal was injected i.p. with saline, risperidone (1-50 $\left.\mathrm{g} \mathrm{kg}^{-1}\right)$, ZJ43 (10-150 $\left.\mathrm{mg} \mathrm{kg}^{-1}\right)$, 2-PMPA (3$150 \mathrm{mg} \mathrm{kg}^{-1}$ ), LY341495 (1 or $3 \mathrm{mg} \mathrm{kg}^{-1}$ ) alone or ZJ43 $\left(150 \mathrm{mg} \mathrm{kg}^{-1}\right.$ ) plus LY341495, and placed back into the chamber for another $15 \mathrm{~min}$. Mice then were given a second i.p. injection with saline, PCP $\left(6 \mathrm{mg} \mathrm{kg}^{-1}\right)$ or $d$-amphetamine $\left(3 \mathrm{mg} \mathrm{kg}^{-1}\right)$. The motor behavior was scored for $50 \mathrm{~min}$ after the second injection. Data are presented as cumulative distance traveled in $\mathrm{cm}$ within the open field chamber. To determine the dose of risperidone that lacked sedative effects, mice were habituated to the testing chamber for $45 \mathrm{~min}$, injected with the drug, returned to the open field chamber and their movement tracked for another $45 \mathrm{~min}$.

To test the efficacy of NAAG peptidase inhibition in reversing ongoing $d$-amphetamine-induced motor activation, C57BL mice were injected (i.p.) with saline or $d$-amphetamine $\left(3 \mathrm{mg} \mathrm{kg}^{-1}\right)$ after $30 \mathrm{~min}$ of habituation to the testing chamber. Saline or $150 \mathrm{mg} \mathrm{kg}^{-1}$ ZJ43 with or without LY341495 was injected $10,15,20$ or 25 min after injection with $d$-amphetamine. The distance travelled was assessed beginning $5 \mathrm{~min}$ after the last injection through the same end point $100 \mathrm{~min}$ after initiation of the habituation (see Figure $2 a$ for time scale). As a result, the 10, 15, 20 and 25 min delay treatment groups for d-amphetamine/saline and d-amphetamine/ZJ43 
treatment groups were scored and statistically compared for motor activation for 55, 50, 45 and 40 min, respectively.

In the standard motor activation test, ambulatory movement was tested after habituation to the chamber at a time, when their spontaneous movement was low relative to that during habituation or that induced by PCP or $d$-amphetamine. Thus, the apparent absence of an effect of the NAAG peptidase inhibitors on movement could be ascribed to a 'floor effect.' To confirm the lack of direct effects of the NAAG peptidase inhibitors on motor function in the open field chamber, C57BL mice were treated with saline $(n=6)$, ZJ43 $\left(150 \mathrm{mg} \mathrm{kg}^{-1}\right.$, $n=7$ ) or 2-PMPA (100 $\mathrm{mg} \mathrm{kg}^{-1}, n=7$ ) $15 \mathrm{~min}$ before being placed into the open field chamber without habituation. Their movement was tracked for $60 \mathrm{~min}$.

GCPII knockout mice. The efficacy of 2-PMPA (100 $\mathrm{mg} \mathrm{kg}^{-1}$, i.p.) in moderating the effects of $6 \mathrm{mg} \mathrm{kg}^{-1}$ of PCP on motor activation in the open field chambers was tested in GCPII knockout mice using the paradigm described above.

Novel object recognition test. Novel object recognition is widely used test for assessing the efficacy of therapeutic approaches to schizophrenia in animal models. ${ }^{13,15,17-20,22,24,47-49}$ C57BL mice were placed individually in a $32 \times 30 \mathrm{~cm}$ box with beige walls for $5 \mathrm{~min}$ habituation followed by injection with saline or ZJ43 (before or after acquisition) or 2-PMPA with and without LY341495 and returned to the chamber. Twenty minutes later mice were injected (i.p.) with saline or $0.2 \mathrm{mg} \mathrm{kg}^{-1} \mathrm{MK}-801$ and 30 min later placed in the chamber with two identical objects for $10 \mathrm{~min}$ (acquisition session). After acquisition, mice were returned to home cages and $1.5 \mathrm{~h}$ later placed back into the testing chamber in the presence of one of the original objects and one novel object of about the same size but a different shape and color (recognition session). The acquisition and recognition sessions were video recorded and the time spent exploring the objects was scored by an observer who was blinded to the drug treatment. Exploratory behavior was defined as sniffing, touching and direct attention to the object. Exploration times are expressed as the means \pm s.e.m. For the acquisition session, the recognition index was calculated as (time exploring one of the objects/ time exploring both the objects) $\times 100$. For the recognition session, the recognition index was calculated as (time exploring the novel object/time exploring both the familiar and the novel object) $\times 100$.

NAAG peptidase inhibitor activity estimated in vivo. To assess the relative NAAG peptidase inhibition obtained with different doses of ZJ43 and 2-PMPA, seven experimental groups were studied. Rats received an i.p. injection of either ZJ43 at $150 \mathrm{mg} \mathrm{kg}^{-1}(n=12), 100 \mathrm{mg} \mathrm{kg}^{-1}(n=8), 50 \mathrm{mg} \mathrm{kg}^{-1}$ $(n=8), 30 \mathrm{mg} \mathrm{kg}^{-1}(n=7), 5 \mathrm{mg} \mathrm{kg}^{-1}(n=9)$ or 2-PMPA at $50 \mathrm{mg} \mathrm{kg}^{-1}(n=6), 10 \mathrm{mg} \mathrm{kg}^{-1}(n=5)$ or $1 \mathrm{mg} \mathrm{kg}^{-1} \quad(n=9)$ $30 \mathrm{~min}$ before injection of $100 \mu$ of $\left[{ }^{3} \mathrm{H}\right]-\mathrm{NAAG}$. A control group $(n=22)$ was given a saline injection 30 min before injection of $\left[{ }^{3} \mathrm{H}\right]-N A A G$. For stereotaxic injection of $\left[{ }^{3} \mathrm{H}\right]-N A A G$ into the lateral ventricle, rats were anesthetized with ketamine and xylazine before injection, maintained under anesthesia for $30 \mathrm{~min}$ and killed by decapitation.
To estimate the time course of ZJ43-mediated NAAG peptidase inhibition, anesthetized rats received i.p. injections of $150 \mathrm{mg} \mathrm{kg}^{-1}$ of ZJ43 at times $15 \mathrm{~min}(n=10), 30 \mathrm{~min}$ $(n=12), 2 \mathrm{~h}(n=8)$, $3 \mathrm{~h}(n=7), 4 \mathrm{~h}(n=10)$ or $5 \mathrm{~h}(n=8)$ before intracerebroventricular injection of radioactive NAAG. Animals were killed after $30 \mathrm{~min}$.

Following decapitation, the brains were removed and immersed in cold $90 \%$ methanol (five times the volume of the brain) and the injection capillary track into the lateral ventricle was confirmed. Brain tissue was homogenized in cold methanol and sedimented for $30 \mathrm{~min}$ at $50000 \mathrm{~g}$. The supernatants dried overnight under vacuum, resuspended in $300 \mu \mathrm{l}$ of $10 \%$ methanol and aliquots were applied to $0.1 \mathrm{M} \mathrm{HCl}$ equilibrated columns of AG 50W-X8 Resin (Bio Rad) prepared in Pasteur pipettes. The columns were washed with $3 \mathrm{ml}$ of $0.1 \mathrm{M} \mathrm{HCl}$ to elute $\left[{ }^{3} \mathrm{H}\right]-\mathrm{NAAG}$ followed by $3 \mathrm{ml}$ of $1 \mathrm{M}$ $\mathrm{HCl}$ to elute $\left[{ }^{3} \mathrm{H}\right]$-glutamate. Radioactivity was measured by liquid scintillation spectroscopy (Beckman, Brea, CA, USA). Relative enzyme activity was estimated as the ratio of $\left[{ }^{3} \mathrm{H}\right]$ glutamate to $\left[{ }^{3} \mathrm{H}\right]-N A A G$. Data from the saline controls was considered basal enzyme activity and all other results were standardized as a percentage of basal activity.

To validate the peptidase inhibition assay, $\left[{ }^{3} \mathrm{H}\right]$-glutamate and $\left[{ }^{3} \mathrm{H}\right]-\mathrm{NAAG}$ in the ion exchange $0.1 \mathrm{M}$ and $1.0 \mathrm{M} \mathrm{HCl}$ eluates were resolved by high-pressure liquid chromatography using a Whatman Partisil $10 \mathrm{SAX}$ column and eluted with sodium phosphate (100 mM, pH 4.9) buffer. Using this highpressure liquid chromatography protocol, the tritium in the resuspended brain extracts comigrated with glutamate and NAAG, with significantly more remaining in the NAAG fraction in the brains from rats that had been treated with ZJ43. The tritium in the fraction that eluted in $0.1 \mathrm{M} \mathrm{HCl}$ comigrated entirely with NAAG standards on high-pressure liquid chromatography and tritium in the fraction that eluted with $1 \mathrm{M} \mathrm{HCl}$ comigrated with the glutamate standard.

Statistical analyses. The open field motor activation and in vivo peptidase inhibition data were analyzed by one- and two-way analysis of variance (ANOVA) using SPSS software 19.0 with GLM procedure with the post-hoc comparisons by Student-Neuman-Keuls test. Significant differences were defined as $P<0.05$.

For the novel object recognition test data, the time spent exploring each object in the novel object discrimination task was analyzed by two-way repeated measures ANOVA, with object and treatment as within and between group variables for both the acquisition and recognition trials. Trial and treatment were used as within and between variables for analyses of the total exploratory activity data. Discrimination ratio data were analyzed by one-way ANOVA followed by Student-Neuman-Keuls post-hoc test.

\section{Results}

PCP-induced motor activation reduced by risperidone. The validity of the PCP-induced motor activation model previously has been reported. ${ }^{13,16}$ To further confirm this in C57BL mice, the efficacy of the atypical antipsychotic risperidone was tested in this model. At $50 \mu \mathrm{g} \mathrm{kg}^{-1}$ (i.p.), 


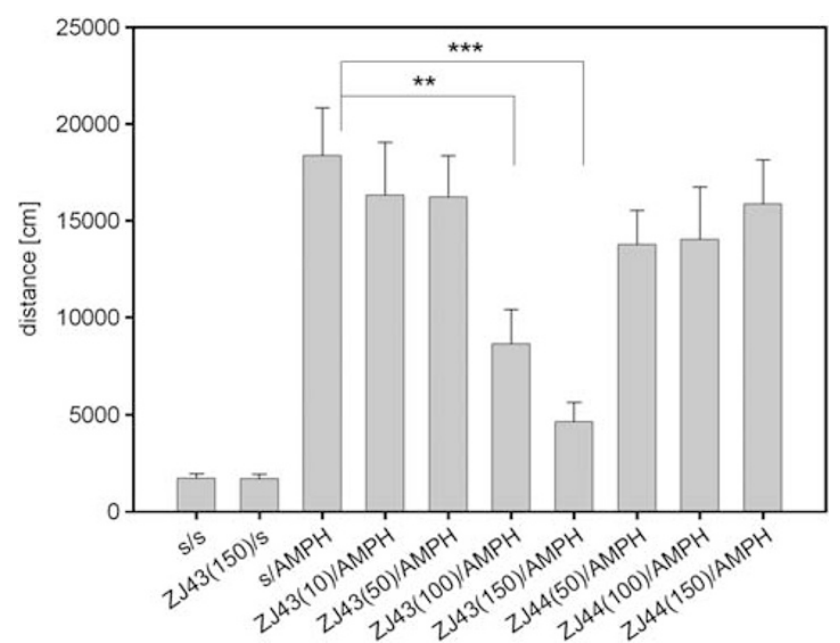

Figure 1 Effects of ZJ43 and ZJ44 on d-amphetamine (AMPH)-induced motor activation. AMPH increased motor activation in C57BL mice as assessed by ambulatory distance travelled in the open field chamber. The $\mathrm{N}$-acetylaspartylglutamate peptidase inhibitor ZJ43 injected (intraperitoneally) 15 min before AMPH significantly lowered the distance traveled for the groups treated with 100 $\left.{ }^{* *} P<0.01\right)$ and $150 \mathrm{mg} \mathrm{kg}^{-1} \mathrm{ZJ} 43\left({ }^{* \star *} P<0.001\right)$. A significant main effect of the drug $(P<0.01)$ and interaction between the drug and treatment $(P<0.001)$ were observed. $n=7-12$ in the saline-treated (s) and $n=11-15$ in the AMPH groups. ZJ44, a structural analogue ZJ43, injected $15 \mathrm{~min}$ before amph, failed to reverse the motor activation with $n=8-12$ animals/group. In this and the following figures ${ }^{\star} P<0.05 ;{ }^{\star \star} P<0.01 ;{ }^{\star \star \star} P<0.001$.

risperidone alone had sedative properties in these mice that reduced motor activation in the open field chamber relative to saline-treated controls (distance travelled over $45 \mathrm{~min}$ following $45 \mathrm{~min}$ habituation to the open field chamber, $521 \pm 182 \mathrm{~cm}$, $n=10$ for risperidone vs $1378 \pm 151 \mathrm{~cm}, n=18$ for saline). Doses of $\leq 10 \mu \mathrm{g} \mathrm{kg}^{-1}(1575 \pm 203 \mathrm{~cm}, n=10)$ did not affect baseline motor activity. At $2 \mu \mathrm{g} \mathrm{kg}^{-1}$, risperidone reduced PCPinduced motor activation (distance traveled over $45 \mathrm{~min}$ : saline $+\mathrm{PCP}, 2692 \pm 396 \mathrm{~cm}, n=7$ vs risperidone $+\mathrm{PCP}$, $1327 \pm 320 \mathrm{~cm}, n=7, P<0.02)$. The percent reduction is comparable with that obtained in this strain of mice with $100 \mathrm{mg} \mathrm{kg}^{-1}$ of 2-PMPA (Figure 3a).

Two NAAG peptidase inhibitors tested in dopamine and glutamate motor activation models of schizophrenia. ZJ43 and 2-PMPA are structurally distinct yet potent inhibitors of GCPII and GCPIII. ${ }^{51-54}$ Each was tested in motor activation models of schizophrenia.

ZJ43 blocked $d$-amphetamine-induced motor activation in C57BL mice (Figure 1), similar to its efficacy in reducing PCPinduced motor activation in rats and 'popping' in Swiss mice $^{32,33}$ In this experiment, there were significant main effects of drug (ZJ43 doses or saline), $\mathrm{F}_{(4,84)}=5.48, P<0.01$, and interactions between drug and treatment $\left(\mathrm{F}_{(3,84)}=7.10\right.$, $P<0.001)$ were observed. ZJ43 reduced the effects of $d$-amphetamine at $100(P<0.01)$ and $150 \mathrm{mg} \mathrm{kg}^{-1}(P<0.001)$ but not at lower doses. Consistent with the conclusion that ZJ43 is acting via its efficacy as a NAAG peptidase inhibitor, 50,100 and $150 \mathrm{mg} \mathrm{kg}^{-1} \mathrm{ZJ} 44$, the less active structural
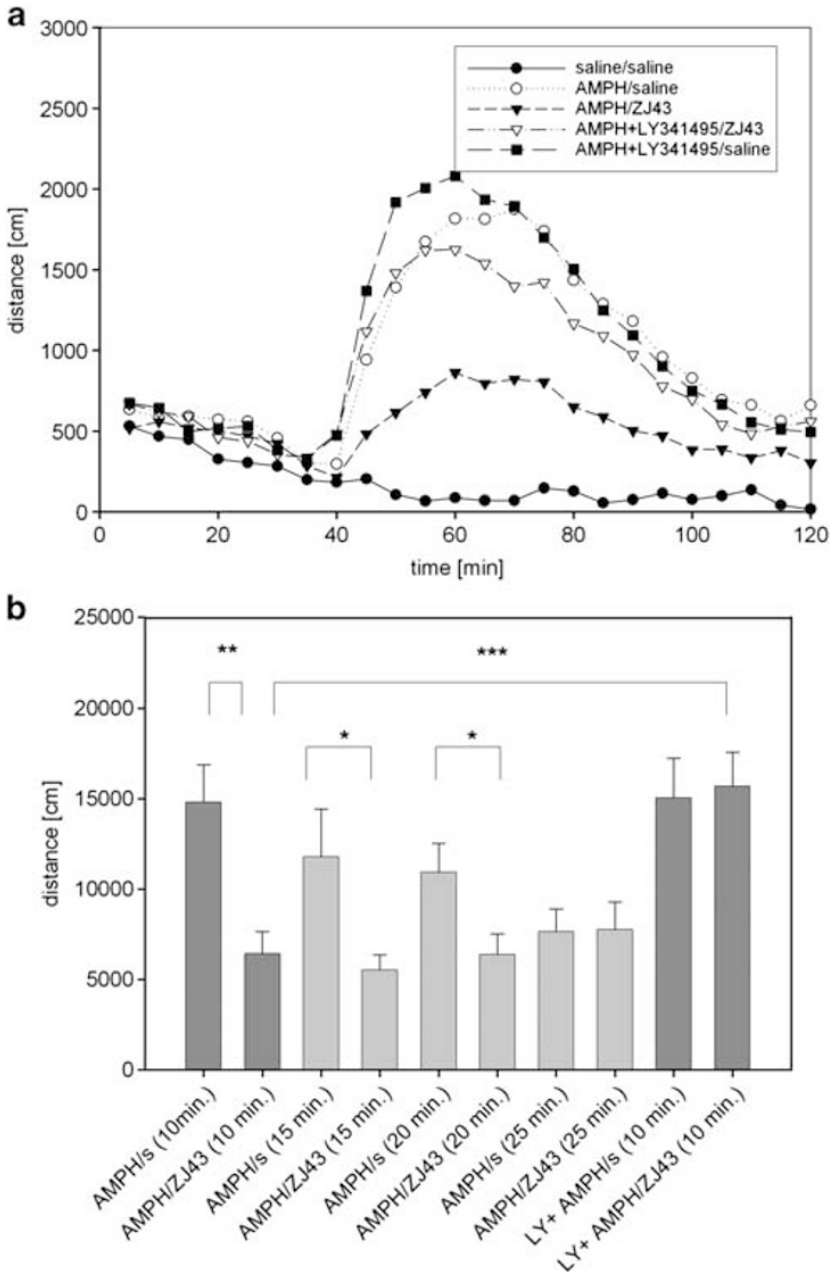

Figure 2 Effects of ZJ43 treatment after onset of $d$-amphetamine (AMPH)induced motor activation in C57BL mice. (a) Time course of AMPH-induced motor activation presented in 5-min intervals. To test the efficacy of $\mathrm{N}$-acetylaspartylglutamate (NAAG) peptidase inhibitor, ZJ43, in the reversal of ongoing AMPH-induced motor activation, animals were habituated in the open field chamber (0-30 min), injected (intraperitoneally (i.p.)) with saline or $3 \mathrm{mg} \mathrm{kg}^{-1} \mathrm{AMPH}$ at the $30 \mathrm{~min}$ time point in this figure. Saline or ZJ43 $\left(150 \mathrm{mg} \mathrm{kg}^{-1}\right.$, i.p.), ZJ43 with LY341495 or LY342495 with saline were injected 10 min later at the 40 min time point. $n=14-16$ animals/group. Coinjection of LY341495 with AMPH did not significantly affect the induced motor activation but did block the effect of ZJ43 on AMPH treatment. (b) Mice received AMPH with or without LY341495 injected at the 30 min time point as in Figure 2a. Saline or ZJ43 was injected 10, 15, 20 and 25 min after AMPH. The distances travelled were measured from the time point $5 \mathrm{~min}$ after the second injection to the $100 \mathrm{~min}$ time point shown in Figure $2 \mathrm{a}$, resulting in distance traveled data over 55, 50, 45 and 40 min intervals for the 10, 15, 20 and 25 min post-MPH treatment groups, respectively. Distance travelled is compared between saline and ZJ43 treatments at each post-AMPH treatment time.

analogue of ZJ43, failed to significantly affect $d$-amphetamine-induced motor activation (Figure 1).

ZJ43 also was administered after $d$-amphetamine treatment to determine its efficacy after initiation of motor activation. ZJ43 $\left(150 \mathrm{mg} \mathrm{kg}^{-1}\right)$ given $10(P<0.01), 15$ and $20 \mathrm{~min}(P<0.05)$ after $d$-amphetamine significantly reduced motor activation relative to saline-treated mice that were assessed over the same time interval (Figures 2a and b). The effect of the peptidase inhibitor given at the $10 \mathrm{~min}$ time point 

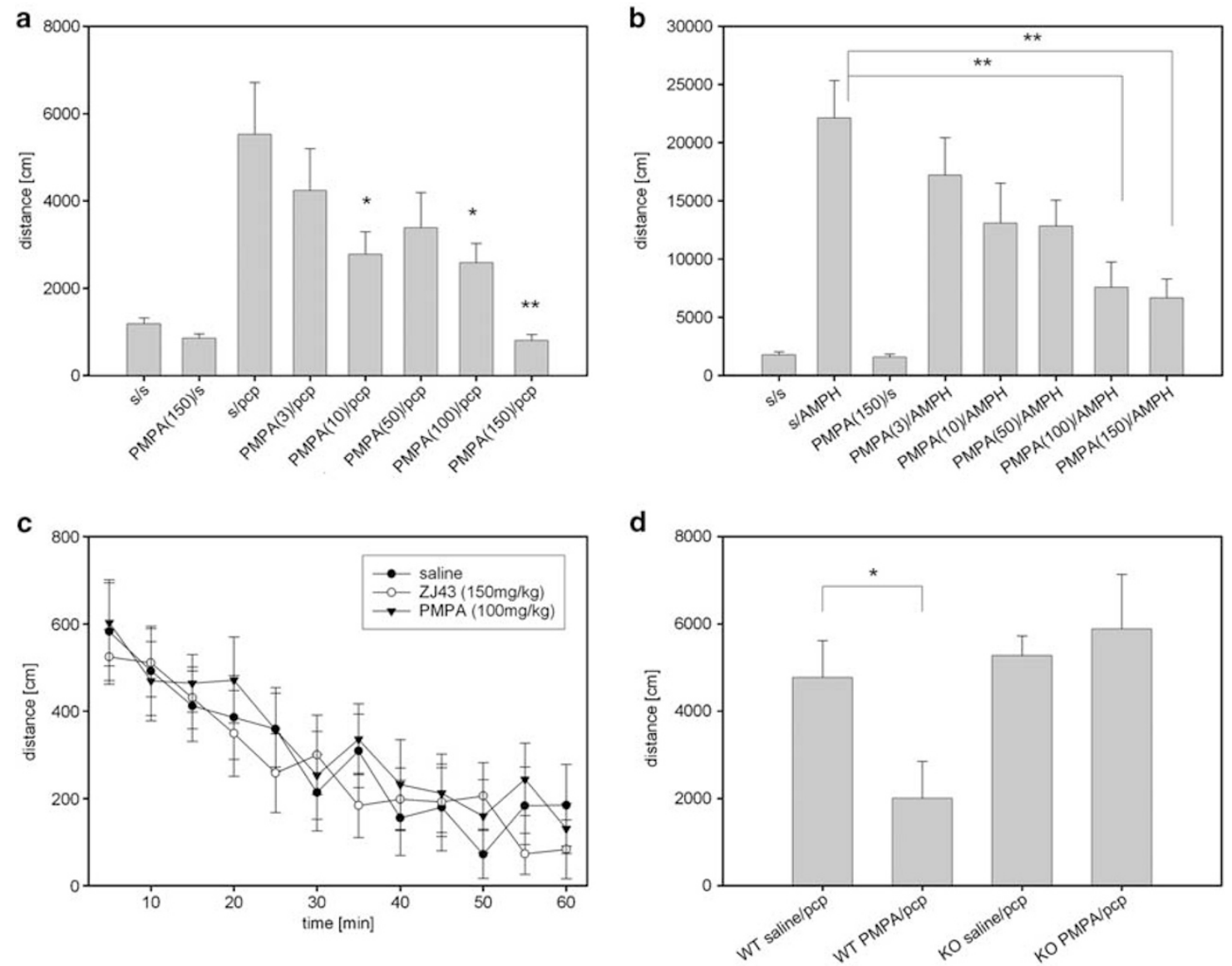

Figure 3 (R,S)-2-phosphono-methylpentanedioic acid (2-PMPA) effects on motor activation of C57BL mice treated with $6 \mathrm{mg} \mathrm{kg}^{-1} \mathrm{phencyclidine} \mathrm{(PCP)} \mathrm{or} 3 \mathrm{mg} \mathrm{kg}^{-1}$ $d$-amphetamine (AMPH). (a) The $\mathrm{N}$-acetylaspartylglutamate (NAAG) peptidase inhibitor 2-PMPA reduced motor activation when injected intraperitoneally (i.p.) 15 min before the treatment with PCP. PCP significantly increased distance travelled vs saline $(P<0.001) .2-\mathrm{PMPA}$ reduced the effects of $\mathrm{PCP}$ at $10,100 \mathrm{and} 150 \mathrm{mg} \mathrm{kg}{ }^{-1} . n=7-12$ per treatment group. (b) 2-PMPA injected i.p. 15 min before treatment with AMPH reduced motor activation in a dose-dependent manner. AMPH significantly $(P<0.001$ compared with saline) increased motor activation. 2-PMPA reduced the effects of AMPH at 100 and $150 \mathrm{mg} \mathrm{kg}^{-1}(P<0.01) . n=8-10$ per treatment group. (c) C57BL mice were treated with saline (s), ZJ43 $\left(150 \mathrm{mg} \mathrm{kg}^{-1}\right)$ or 2-PMPA $\left(100 \mathrm{mg} \mathrm{kg}^{-1}\right) 15$ min before being placed into the open field chamber without habituation. Their movement was tracked for 60 min. No significant effect of the drugs on motor activity was detected. $n=6-7$ per treatment group. (d) The efficacy of 2-PMPA $\left(100 \mathrm{mg} \mathrm{kg}^{-1}\right)$ was tested in glutamate carboxypeptidase II (GCPII) knockout (KO) mice and their wild-type (WT) colony mates. 2-PMPA did not produce a significant effect on PCP-induced motor activation in the mice lacking the NAAG peptidase GCPII, whereas it was effective in decreasing motor activation in WT mice $(P<0.05) . n=6-7$ per treatment group.

was blocked by coadministration of the mGluR2/3 antagonist LY341495, whereas the antagonist alone had no effect on the induced motor activation.

To test the conclusion that the previously reported effects of ZJ43 in PCP models of schizophrenia were mediated via NAAG peptidase inhibition, the efficacy of 2-PMPA also was tested. 2-PMPA dose-dependently blocked the effects of PCP in DBA2 mice. There was a significant main effect of drug (saline and doses of 2-PMPA), $\left(F_{(5,55)}=9.41, P<0.001\right)$. Posthoc analysis revealed significant differences between the $\mathrm{PCP}$ treatment group and the 2-PMPA/PCP groups at 50 $(P<0.001), 100(P<0.01)$ and $150 \mathrm{mg} \mathrm{kg}^{-1}(P<0.001)$ doses of 2-PMPA but not at 10 or $25 \mathrm{mg} \mathrm{kg}^{-1}$.

ZJ43 at doses as high as $150 \mathrm{mg} \mathrm{kg}^{-1}$ failed to block the effects of PCP in C57BL mice (s/PCP $4191 \pm 607$ and 150 ZJ43/PCP $3837 \pm 782$ in $\mathrm{cm}$ travelled), while it blocked the effects of $d$-amphetamine in this strain (Figure 1). As differences in drug efficacy among mice with different genetic backgrounds are well established, the efficacy of 2-PMPA was also tested against PCP in C57BL mice and found to be effective (Figure 3a). A significant effect of drug (saline and doses of 2-PMPA), $\left(\mathrm{F}_{(5,53)}=3.40, P<0.05\right)$ was observed. Post-hoc analysis revealed significant differences between PCP and 2-PMPA/PCP treatment groups for following doses of 2-PMPA: $10(P<0.05), 100(P<0.05)$ and $150 \mathrm{mg} \mathrm{kg}^{-1}$ $(P<0.01)$.

2-PMPA was tested further in the $d$-amphetamine model (Figure $3 b$ ). There was a significant difference between treatments $\left(F_{(7,68)}=8.02, P<0.01\right)$. At 100 and $150 \mathrm{mg} \mathrm{kg}^{-1}$, 2-PMPA significantly $(P<0.01)$ reduced the motor activation induced by $d$-amphetamine.

ZJ43 and 2-PMPA alone do not inhibit motor function. ZJ43 (150 $\mathrm{mg} \mathrm{kg}^{-1}$ ) and 2-PMPA (100 $\mathrm{mg} \mathrm{kg}^{-1}$ ) did not significantly affect baseline motor activity as assessed after habituation to the open field chamber (Figures 1 and $3 a$ ). To test the possibility that a 'floor effect' precluded detection of a direct effect of these drugs on motor activity, C57BL mice 
that had not been habituated to the open field chamber were treated (i.p.) with saline, $150 \mathrm{mg} \mathrm{kg}^{-1} \mathrm{ZJ} 43$ or $100 \mathrm{mg} \mathrm{kg}^{-1}$ 2-PMPA $15 \mathrm{~min}$ before placing them in open field chambers. Neither drug significantly affected the total distance traveled over $60 \mathrm{~min}$ relative to saline (saline $3526 \pm 475 \mathrm{~cm}$; ZJ43 $3307 \pm 218 \mathrm{~cm}$; 2-PMPA $3929 \pm 402 \mathrm{~cm}$ ). Similarly, when the data were assessed as distance travelled in 5-min intervals over the $60 \mathrm{~min}$, no significant differences emerged (Figure $3 \mathrm{c}$ ). These results support the conclusion that these doses of ZJ43 and 2-PMPA do not have generalized motor activity suppression effects that would compromise interpretation of their effects in PCP and $d$-amphetaminebased motor activation studies.

Effects of 2-PMPA mediated by inhibition of GCPII: study in knockout mice. In a study of GCPII knockout mice and their wild-type colony mates (Figure $3 d$ ), there was a significant effect of genotype $\left(F_{(1,23)}=5.62, P<0.05\right)$ with significant difference between wild-type groups (PCP treatment vs 2PMPA/PCP $(P<0.05))$. 2-PMPA $\left(100 \mathrm{mg} \mathrm{kg}^{-1}\right)$ reduced the effect of PCP in wild-type mice, but failed to affect motor activation induced by PCP in GCPII knockout mice.

NAAG peptidase inhibitors tested in model of a schizophrenia-like cognitive deficit. The novel object recognition test has been widely used in conjunction with open channel NMDA receptor antagonists to model schizophrenia-like cognitive impairment. ${ }^{13,18,20,22,24,48,49}$ To test the efficacy of NAAG peptidase inhibition in this model, C57BL mice were injected with saline, ZJ43 (150 $\mathrm{mg} \mathrm{kg}^{-1}$ ), 2-PMPA (100 $\left.\mathrm{mg} \mathrm{kg}^{-1}\right)$ or LY341495 (1 and $\left.3 \mathrm{mg} \mathrm{kg}^{-1}\right) 20 \mathrm{~min}$ before injection with saline or MK-801 $\left(0.2 \mathrm{mg} \mathrm{kg}^{-1}\right)$. Thirty minutes later, they were placed in a chamber with two identical objects (acquisition session). Mice in each group explored the two objects nearly equal amounts of time (Figure 4a). When presented with one of the original objects and one novel object $1.5 \mathrm{~h}$ later (recognition session), saline-treated (control) mice spent about twice as much time exploring the novel object as the familiar object. By contrast, the mice treated with this low dose of MK-801 failed to discriminate the novel object and spent equal time exploring the novel and familiar objects, a result taken to indicate a failure to recall the objects presented during the acquisition session.

ZJ43 dose-dependently blocked the cognitive effects of MK801 in the novel object recognition test (Figure 4a). There was a significant main effect of drug $\left(F_{(4,104)}=12.91, P<0.001\right)$, and significant differences between treatments $(P<0.001)$ and sessions $(P<0.001)$. There also was a significant interaction between session and drug $\left(\mathrm{F}_{(4,104)}=9.92, P<0.001\right)$. Posthoc analysis revealed significant differences between the saline-MK-801- and ZJ43-MK-801-treated groups for $100 \mathrm{mg} \mathrm{kg}^{-1} \quad(P<0.05)$ and $150 \mathrm{mg} \mathrm{kg}^{-1}(P<0.001)$ ZJ43. The ZJ43-treated mice like the saline-treated controls also spent twice as much time exploring the novel object as the familiar one.

In this assay, MK-801 is reported to affect acquisition rather than consolidation of memory. ${ }^{56}$ In order to discriminate between the effects of ZJ43 on acquisition and consolidation of short-term memory, mice were also treated with ZJ433 (100 $\mathrm{mg} \mathrm{kg}^{-1}$ ) $10 \mathrm{~min}$ after the acquisition session rather than
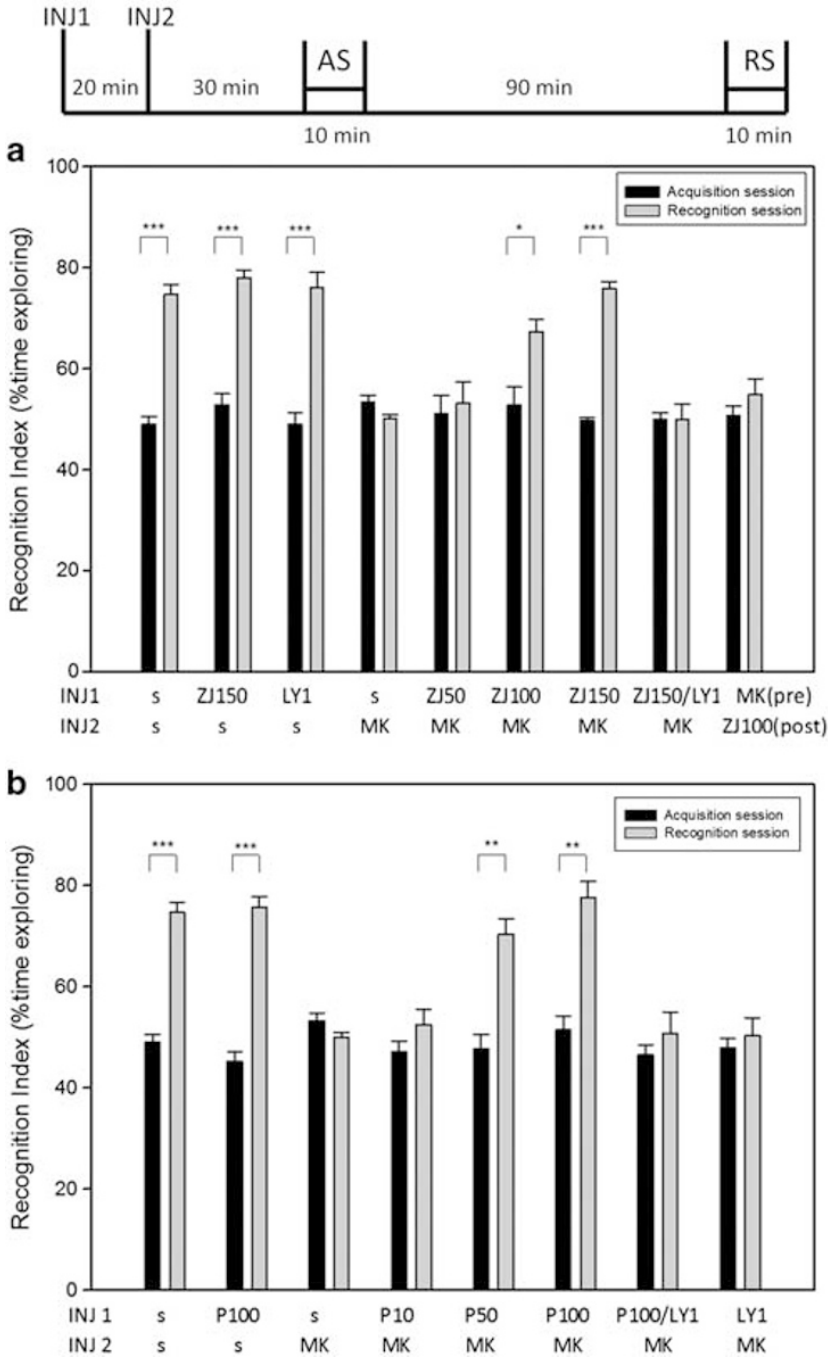

Figure 4 Effects of ZJ43 and (R,S)-2-phosphono-methylpentanedioic acid (2-PMPA) on dizocilpine (MK-801)-induced cognitive deficit in the novel object recognition test. C57BL mice were injected (INJ) with by MK-801 $\left(0.2 \mathrm{mg} \mathrm{kg}^{-1}\right.$, intraperitoneally (i.p.)) or saline $20 \mathrm{~min}$ after i.p. injection with: (a) saline (s), ZJ43 (50, 100 or $150 \mathrm{mg} \mathrm{kg}^{-1}$ ) or $150 \mathrm{mg} \mathrm{kg}^{-1}$ ZJ43 with LY341495 $\left(1 \mathrm{mg} \mathrm{kg}^{-1}\right)$; (b) 2-PMPA (10, 50, $\left.100 \mathrm{mg} \mathrm{kg}^{-1}\right), 100 \mathrm{mg} \mathrm{kg}^{-1}$ 2-PMPA with LY341495 $\left(1 \mathrm{mg} \mathrm{kg}^{-1}\right)$, or LY341495 $\left(1 \mathrm{mg} \mathrm{kg}^{-1}\right)$ and 30 min later placed in a chamber with two identical objects for a 10-min acquisition session (AS) $30 \mathrm{~min}$. Mice were tested with one original and one novel object in a recognition session (RS) 90 min after the AS. The recognition index for the AS was calculated as: (time exploring one of the objects/ time exploring both the objects) $\times 100$. For the RS, the recognition index was calculated as: (time exploring the novel object/ time exploring the familiar and the novel object) $\times 100$. (a) Saline-treated mice attended the novel object about twice as much as the familiar object. MK801 given before the AS blocked memory of the familiar object during the RS. ZJ43 (100 and $150 \mathrm{mg} \mathrm{kg}^{-1}$ ) blocked the effects of MK-801. The effect of ZJ43 $\left(150 \mathrm{mg} \mathrm{kg}^{-1}\right)$ on MK-801 was reversed by $1 \mathrm{mg} \mathrm{kg}^{-1}$ of the metabotropic glutamate receptor $2 / 3$ antagonist LY341495. ZJ43 $\left(100 \mathrm{mg} \mathrm{kg}^{-1}\right)$ was not effective in blocking the MK-801 effect when given immediately after the AS. $n=9-24$ mice per group. (b) 2-PMPA doseresponse on MK-801-induced cognitive deficits in the novel object recognition test. 2-PMPA (100 and $150 \mathrm{mg} \mathrm{kg}^{-1}$ ) blocked the effect of MK-801. LY341495 $\left(1 \mathrm{mg} \mathrm{kg}^{-1}\right)$ blocked the effect of 2-PMPA $\left(100 \mathrm{mg} \mathrm{kg}^{-1}\right)$ on MK-801. $n=5-24$ mice per group. Data for the saline (s-s) and saline + MK-801 (s MK) are the same as in $\mathbf{a}$ and $\mathbf{b}$, respectively. 
before. This treatment failed to block the recognition memory deficit induced by MK-801 (Figure 4a).

2-PMPA also blocked the effects of MK-801 in the novel object recognition test in a dose dependent manner (Figure 4b). There was a significant main effect of drug $\left(F_{(5,78)}=6.76, P<0.001\right)$ and interaction between session and drug $\left(F_{(5,78)}=7.59, P<0.001\right)$. 2-PMPA at 50 and $100 \mathrm{mg} \mathrm{kg}^{-1}$ blocked the effect of MK801 on novel object recognition $(P<0.01)$, whereas it had no effect at $10 \mathrm{mg} \mathrm{kg}^{-1}$.

No significant effect of drug ZJ43, 2-PMPA or LY341495 (1 $\mathrm{mg} \mathrm{kg}^{-1}$ ) alone was observed on recognition (Figures $4 \mathrm{a}$ and b). At $1 \mathrm{mg} \mathrm{kg}^{-1}$, the group II mGluR antagonist blocked the effect of $150 \mathrm{mg} \mathrm{kg}^{-1} \mathrm{ZJ} 43$ and $100 \mathrm{mg} \mathrm{kg}^{-1}$ 2-PMPA. By contrast, at $3 \mathrm{mg} \mathrm{kg}^{-1}$, LY341495 blocked recognition of the novel object (recognition index of $51.49 \pm 2.42$ for acquisition session and $55.68 \pm 0.75$ for recognition session).

The exploration times among the drug treatment groups did not differ significantly although the saline/saline treatment group showed a non-significant tendency to be higher than the other treatment groups (data not shown).

Dose dependence of ZJ43 and 2-PMPA on NAAG peptidase activity in vivo. Although ZJ43 and 2-PMPA have similar potencies as inhibitors of GCPII in vitro, the data presented here and other studies ${ }^{57}$ indicate that 2-PMPA is more potent in vivo. To confirm that this is due to greater inhibition of brain NAAG peptidase activity following i.p. administration of these inhibitors, the rate of $\left[{ }^{3} \mathrm{H}\right]-\mathrm{NAAG}$ hydrolysis was assessed in the rat brain in vivo. This radiochemical method does not attempt to produce an absolute measure of NAAG peptidase activity in vivo, but rather to provide relative values under well-defined conditions than can be used as reference points for interpreting the efficacy of ZJ43 and 2-PMPA in behavioral studies. ZJ43 (30$150 \mathrm{mg} \mathrm{kg}^{-1}$ ) and 2-PMPA (10 and $50 \mathrm{mg} \mathrm{kg}^{-1}$ ) produced significant inhibition of NAAG hydrolysis as measured over the interval from 30-60 min after i.p. injection of the inhibitor (Figure 5a). ANOVA showed significant differences between the groups in ZJ43 $\left(\mathrm{F}_{(5,65)}=43.939, P<0.001\right)$ and 2-PMPA $\left(\mathrm{F}_{(3,43)}=238.551, \quad P<0.001\right)$ dose responses. Using this scale of relative NAAG peptidase activity, there was a $40 \%$ decrease in $\left.{ }^{3} \mathrm{H}\right]-\mathrm{NAAG}$ hydrolysis following administration of $100 \mathrm{mg} \mathrm{kg}^{-1}$ of ZJ43. At $50 \mathrm{mg} \mathrm{kg}^{-1}$, this value fell to about $15 \%$, differing significantly from both 100 and $150 \mathrm{mg} \mathrm{kg}^{-1}$ $(P<0.001)$. 2-PMPA at 10 and $50 \mathrm{mg} \mathrm{kg}^{-1}$ inhibited $\left[{ }^{3} \mathrm{H}\right]$ NAAG hydrolysis by 50 and $80 \%$ respectively. Inhibition at $50 \mathrm{mg} \mathrm{kg}^{-1}$ was significantly different from $10 \mathrm{mg} \mathrm{kg}^{-1}$ $(P<0.001)$. 2-PMPA at $10 \mathrm{mg} \mathrm{kg}^{-1}$ was significantly more effective than the $50 \mathrm{mg} \mathrm{kg}^{-1}$ dose of ZJ43 $(P<0.001)$ and $50 \mathrm{mg} \mathrm{kg}^{-1}$ 2-PMPA produced significantly greater NAAG peptidase inhibition than 100 and $150 \mathrm{mg} \mathrm{kg}^{-1}$ ZJ43 (both at $P<0.001)$.

Time course of ZJ43 inhibition in the rat brain. Inhibition of $\left[{ }^{3} \mathrm{H}\right]-N A A G$ hydrolysis was tested over 30-min intervals starting 15, $30 \mathrm{~min}, 2,3,4$ and $5 \mathrm{~h}$ after injection of ZJ43 (150 $\mathrm{mg} \mathrm{kg}^{-1}$, i.p.; Figure 5b). One-way ANOVA showed significant differences between groups $\left(F_{(6,66)}=18.488\right.$, $P<0.001)$. Of the time intervals tested, maximum inhibition was achieved in the 15-30-min assay interval. The inhibition
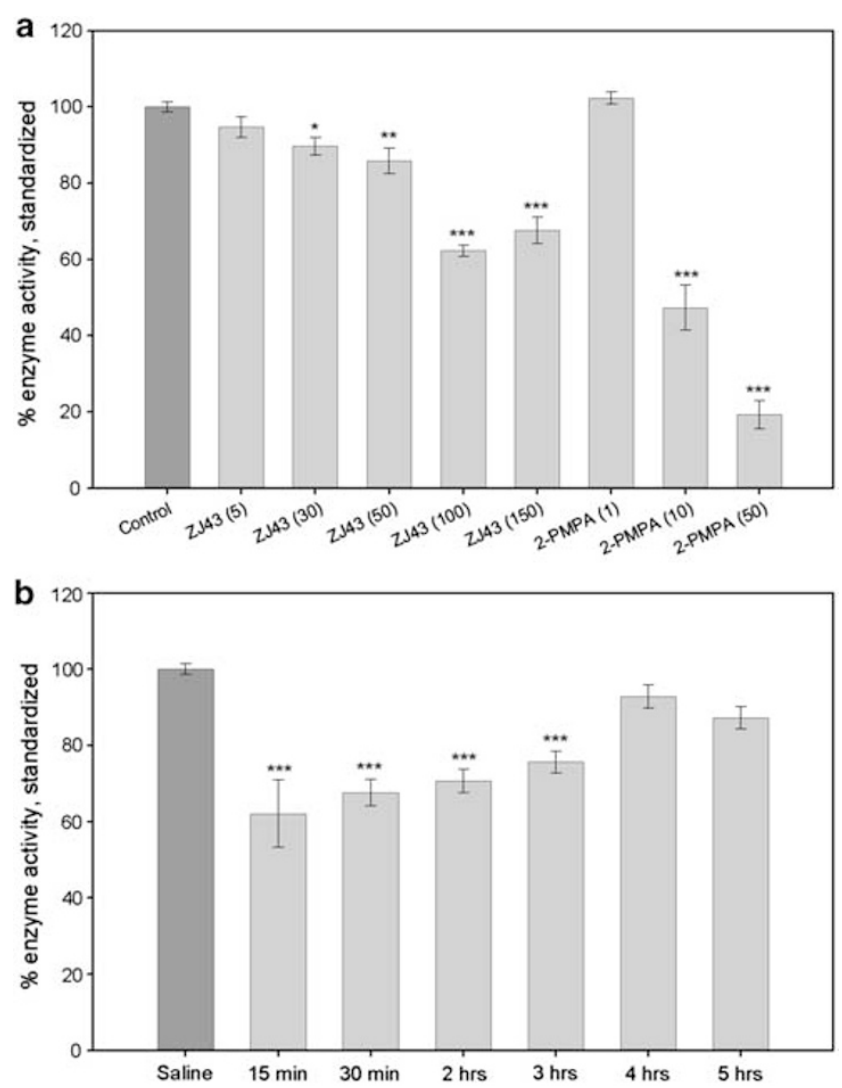

Figure 5 Relative efficacy of ZJ43 and (R,S)-2-phosphono-methylpentanedioic acid (2-PMPA) in inhibition of $\mathrm{N}$-acetylaspartylglutamate (NAAG) peptidase activity in vivo. (a) Saline or the peptidase inhibitors were injected (intraperitoneally (i.p.)) $30 \mathrm{~min}$ before injection of $\left[{ }^{3} \mathrm{H}\right]-\mathrm{NAAG}$ into the lateral ventricle. Relative peptidase inhibition is estimated as a percent of $\left[{ }^{3} \mathrm{H}\right]$-glutamate released from $\left[{ }^{3} \mathrm{H}\right]-\mathrm{NAAG}$ over $30 \mathrm{~min}$ following $\left[{ }^{3} \mathrm{H}\right]-\mathrm{NAAG}$ injection. [ $\left.{ }^{3} \mathrm{H}\right]-\mathrm{NAAG}$ hydrolysis (enzyme activity) is expressed relative to the saline treatment group as $100 \%$. Control group $n=27$; other treatment groups $n=7-12$. (b) $\left[{ }^{3} \mathrm{H}\right]-\mathrm{NAAG}$ was injected at different intervals after i.p. injection of ZJ43 at $150 \mathrm{mg} \mathrm{kg}^{-1}$ (i.p.) and hydrolysis was followed over $30 \mathrm{~min}$ intervals as in a. All values are means \pm s.e.m. Saline group $n=20$; treatment groups $n=8-12$.

was significant $(P<0.001)$ relative to control values at each time point up to and including $3 \mathrm{~h}$.

\section{Discussion}

A series of studies have reported genetic associations of polymorphisms in mGluR3 with schizophrenic and bipolar subjects (reviewed in Harrison et al. ${ }^{7}$ and Sartorius et al. ${ }^{58}$ ). Post-mortem examination of brains from schizophrenic subjects revealed decreases in mGluR3 and increases in GCPII protein in the dorsolateral prefrontal cortex, ${ }^{59}$ alterations in the concentrations of mGluR3 and GCPII mRNA in the anterior hippocampus ${ }^{60}$ and a decrease in the ratio of dimeric vs monomeric forms of this mGluR3 in the Brodmann area. ${ }^{61}$ Although these post-mortem data suggest that mGluR3mediated neurotransmission may be altered in schizophrenia, their significance was advanced by studies on the efficacy of mGluR2/3 agonists in animal models of this disorder $^{16,21,34,35,39}$ and by some clinical trial data. ${ }^{8,38,42,43}$ In contrast to these data suggesting involvement of mGluR3 in 
schizophrenia, the mGluR2/3 agonists LY354740 and LY379268 are affective in blocking PCP-induced motor activation in mGluR3 but not mGluR2 knockout mice. ${ }^{25,36}$ These data support mGluR2 as the site of action of these agonists in the PCP-based model of schizophrenia and are consistent with their efficacy in activation of mGluR2 in vitro. ${ }^{23,44}$ Also supporting an antipsychotic role for mGluR2 activation, positive allosteric modulators of this receptor are effective in moderating PCP-induced motor activation and prepulse inhibition of acoustic startle. .,62 $^{-6}$

In contrast to mGluR2/3 agonists, NAAG is selective for mGluR3. ${ }^{27}$ The foundation for the conclusion that NAAG peptidase inhibitors, acting via NAAG activation of mGluR3, has potential as an antipsychotic therapy derives from studies in which ZJ43 reduced positive and negative behaviors in validated PCP-based animal models of schizophrenia. ${ }^{32,33}$ Importantly, ZJ43 is not active as an agonist or antagonist at mGluRs, including mGluR2 and mGluR3, and its effects in vivo are blocked by co-administration of the mGluR2/3 antagonist LY341495. ${ }^{31-33,52,57,63}$ Recently, we found that NAAG peptidase inhibition moderates the motor activation effects of PCP in mGluR2 but not in mGluR3 knockout mice, reinforcing the conclusion that these inhibitors are acting via NAAG activation of mGluR3 rather than mGluR2. ${ }^{29}$ Nonetheless, proof of the concept that NAAG peptidase inhibitors have antipsychotic-like efficacy in animal models was lacking several important elements: demonstration of the efficacy of structurally different NAAG peptidase inhibitors; tests of ZJ43 and 2-PMPA in validated dopamine models of this disorder; tests of a structural analogue of ZJ43 that lacked potency as NAAG peptidase inhibitors; confirmation of GCPII as the NAAG peptidase inhibitor in knockout mice; and assays in cognitive deficit models of the disorder. The data presented here addresses each of these issues.

2-PMPA is a potent NAAG peptidase inhibitor ${ }^{30,53,54}$ that also fails to act as an mGluR agonist or antagonist. ${ }^{57}$ By contrast, ZJ44, which differs from ZJ43 by a $-\mathrm{CH} 2$ group, is 50 -fold less potent than ZJ43 as a NAAG peptidase inhibitor (data in the Methods setion). The efficacy of 2-PMPA in the PCP motor activation models (Figures $3 a$ and b) and the failure of ZJ44 $\left(150 \mathrm{mg} \mathrm{kg}^{-1}\right)$ to block the effects of $d$-amphetamine (Figure 1) are consistent with our model of action of NAAG peptidase inhibition in the schizophrenia models. ${ }^{28,45}$ The efficacy of 2-PMPA in the PCP model using C57BL mice when $150 \mathrm{mg} \mathrm{kg}^{-1}$ of ZJ43 failed to reduce the effects of PCP in this strain is most likely due to the greater in vivo efficacy of the former inhibitor. As they are nearly equipotent in vitro, this difference in vivo would appear to be due to better brain penetration by 2-PMPA, a concept that is supported by the in vivo peptidase inhibition data (Figure 5).

Although glutamate models of schizophrenia based on the open channel NMDA receptor blockers are well validated, most antipsychotic drugs also are effective in dopamine models of this disorder. The group II mGluR agonists meet this criterion. ${ }^{35}$ Given the apparently different receptor targets of the mGluR2/3 agonists and NAAG in the PCP studies, the observation that ZJ43 and 2-PMPA reduce $d$-amphetamineinduced motor activation (Figures 1 and $3 b$ ) represents another important step in establishing the preclinical efficacy of this class of drugs.
Under clinical conditions, antipsychotic drugs necessarily are given after onset of symptoms. Addressing this point, ZJ43 was efficacious $(P<0.05)$ when administered as late as 20 min after treatment with $d$-amphetamine (Figure $2 b$ ).

Currently approved antipsychotic drugs have limited efficacy in treating cognitive deficits, including short-term memory dysfunction, that are associated with schizophrenia. Group I and II mGluR agonists have shown some efficacy in animal models of cognitive schizophrenic deficits and in early clinical trials. ${ }^{9,14,42,47}$ The mGluR2/3 agonist LY354740 modestly reduced the deficit induced by PCP in a delayed alternation memory test and was more effective when tested against a low dose of MK-801. ${ }^{21,64}$ By contrast, LY354740 failed to affect PCP-induced deficits in spontaneous delayed alternation or a passive avoidance tasks. ${ }^{40}$ Similarly, the mGluR2 positive allosteric modulator LY487379 had no effect in the MK-801-induced deficits in the active allothetic place avoidance task. ${ }^{41}$ Post-weaning social isolation in rats produces some of the core symptom deficits observed in schizophrenia. The mGluR2/3 agonist LY379268 improved declarative recognition memory deficits in this developmental model as assessed in the novel object recognition test. ${ }^{37}$ In that study, however, the agonist appeared to block novel object recognition in group-reared control rats.

In the present study, the group II mGluR antagonist LY341495 $\left(1 \mathrm{mg} \mathrm{kg}^{-1}\right)$ given before the acquisition trial, did not affect novel object recognition $1.5 \mathrm{~h}$ later. However, at $3 \mathrm{mg} \mathrm{kg}^{-1}$, LY341495 alone blocked retention. By contrast, Baker et al. ${ }^{15}$ reported that $3 \mathrm{mg} \mathrm{kg}^{-1} \mathrm{LY} 341495$ did not significantly affect short-term memory in the novel object recognition test in a rat strain. At $1 \mathrm{mg} \mathrm{kg}^{-1}$, this antagonist improved spatial learning in the water maze assay. ${ }^{47} \mathrm{~A}$ different group II antagonist MGS0039 enhanced social memory in rats. ${ }^{65}$ Some of these apparently conflicting results may be explained by data from mGluR2 and mGluR3 knockout mice in which $3 \mathrm{mg} \mathrm{kg}^{-1}$ LY341495 elicits neuronal activation and inhibition in different brain regions that are not mediated by group II mGluRs, but possibly mGluR7 and mGluR8. ${ }^{66}$

The MK-801-induced deficits in the visual recognition memory test are reversed by second generation antipsychotics, ${ }^{17,22}$ a result that contributes to the validation of this assay for tests of novel antipsychotic drugs. ${ }^{13,18-20,48}$ The data on ZJ43- and 2-PMPA-mediated blockade of the effects of MK801 in this test (Figures $4 \mathrm{a}$ and b) provide the first evidence of the potential of NAAG peptidase inhibitors to affect cognitive behaviors in a schizophrenia model. When administered before the acquisition session, MK-801 blocks encoding of object recognition but when given after this session, it does not affect consolidation or retrieval processing. ${ }^{56}$ By blocking this effect of MK-801, it appears that NAAG peptidase inhibition also affects the acquisition phase. The possibility that NAAG is enhancing post-trial consolidation is ruled out by the failure of ZJ43 to block MK-801 when given after the acquisition session (Figure $4 \mathrm{a}$ ). Blockade of the cognitive effects of ZJ43 and 2-PMPA by LY341495 $\left(1 \mathrm{mg} \mathrm{kg}^{-1}\right)$ is consistent with the conclusion that NAAG activation of mGluR3 mediates this action. The efficacy of NAAG in this study may be related to the reported influence of genetic variants in mGluR3 on cognition in schizophrenic and healthy subjects. ${ }^{67-69}$ 
Figure 5 provides the first data on the relative efficacy of systemically administered ZJ43 and 2-PMPA on NAAG peptidase activity under the same assay conditions in vivo. Importantly, a $50 \mathrm{mg} \mathrm{kg}^{-1}$ dose of 2-PMPA inhibited about five times better than an equal dose of ZJ43 under the conditions of this assay even though the two have similar $\mathrm{IC}_{50}$ (concentration for $50 \%$ inhibition) values in vitro. ${ }^{30,32}$ This is consistent with the efficacy of 2-PMPA in moderating PCP-induced motor activation in C57BL mice, whereas $150 \mathrm{mg} \mathrm{kg}^{-1}$ of ZJ43 failed to have an effect in blocking the effects of MK801 in the novel object recognition test and in studies of the analgesic effects of these two inhibitors in rats. ${ }^{57}$ Importantly, there is very little difference in the level of inhibition during the first $3 \mathrm{~h}$ following treatment with the ZJ43 (Figure $5 \mathrm{~b}$ ), a result that is consistent with the drug acting during the entirety of the PCP-induced motor activity assay interval.

Taken together with the earlier studies of the efficacy of ZJ43 in animal models of the positive and negative schizophrenialike behaviors, ${ }^{32,33}$ these data contribute to the proof of the concept that NAAG peptidase inhibitors might have potential for development as antipsychotic drugs. Inasmuch as their efficacy is based on mGluR3 agonism, rather than direct activity at dopamine or serotonin receptors, they could also offer promise as adjuvant drugs administered with atypical antipsychotics.

\section{Conflict of interest}

The authors declare no conflict of interest.

Acknowledgements. Although the patent for ZJ43 is held by Georgetown University, we have no proprietary interest in this compound or 2-PMPA. This research was supported by $\mathrm{NIH} \mathrm{(R01} \mathrm{MH} \mathrm{79983)} \mathrm{and} \mathrm{by} \mathrm{an} \mathrm{endowment} \mathrm{and}$ generous gifts from Nancy and Daniel Paduano. JCM, KML, JC-ML, MJL, CPP, TJH and PRF were supported by a grant to Georgetown University (JHN) from the Howard Hughes Medical Institute through the Precollege and Undergraduate Science Education Program. We thank Jacqueline Crawley for reviewing an earlier version of this manuscript.

1. Javitt DC. Glutamate and schizophrenia: phencyclidine, $N$-methyl-D-aspartate receptors, and dopamine-glutamate interactions. Int Rev Neurobiol 2007; 78: 69-108.

2. Ross CA, Margolis RL, Reading SA, Pletnikov M, Coyle JT. Neurobiology of schizophrenia Neuron 2006; 52: 139-153.

3. Shohamy D, Mihalakos P, Chin R, Thomas B, Wagner AD, Tamminga C. Learning and generalization in schizophrenia: effects of disease and antipsychotic drug treatment. Bio Psychiatry 2010; 67: 926-932.

4. Stone WS, Hsi X. Declarative memory deficits and schizophrenia: problems and prospects. Neurobiol Learn Mem 2011; 96: 544-552.

5. Tamminga CA. The neurobiology of cognition in schizophrenia. J Clin Psychiatry 2006; 67(Suppl 9): 9-13.

6. Gregory KJ, Dong EN, Meiler J, Conn PJ. Allosteric modulation of metabotropic glutamate receptors: structural insights and therapeutic potential. Neuropharmacology 2011; 60 : 66-81.

7. Harrison PJ, Lyon L, Sartorius LJ, Burnet PW, Lane TA. The group II metabotropic glutamate receptor 3 (mGluR3, mGlu3, GRM3): expression, function and involvement in schizophrenia. J Psychopharmacol 2008; 22: 308-322.

8. Krystal JH, Mathew SJ, D'Souza DC, Garakani A, Gunduz-Bruce H, Charney DS. Potential psychiatric applications of metabotropic glutamate receptor agonists and antagonists. CNS Drugs 2010; 24: 669-693.

9. Marek GJ. Metabotropic glutamate2/3 (mGlu2/3) receptors, schizophrenia and cognition. Eur J Pharmacol 2010; 639: 81-90.

10. Niswender CM, Conn PJ. Metabotropic glutamate receptors: physiology, pharmacology, and disease. Annu Rev Pharmacol Toxicol 2010; 50: 295-322.
11. Perala J, Suvisaari J, Saarni SI, Kuoppasalmi K, Isometsa E, Pirkola S et al. Lifetime prevalence of psychotic and bipolar I disorders in a general population. Arch Gen Psychiatry 2007; 64: 19-28.

12. Carlsson A, Carlsson ML. A dopaminergic deficit hypothesis of schizophrenia: the path to discovery. Dialogues Clin Neurosci 2006; 8: 137-142

13. Amann LC, Gandal MJ, Halene TB, Ehrlichman RS, White SL, McCarren HS et al. Mouse behavioral endophenotypes for schizophrenia. Brain Res Bull 2010; 83: 147-161.

14. Amitai N, Markou A. Disruption of performance in the five-choice serial reaction time task induced by administration of $\mathrm{N}$-methyl-D-aspartate receptor antagonists: relevance to cognitive dysfunction in schizophrenia. Biol Psychiatry 2010; 68: 5-16.

15. Baker M. Animal models: inside the minds of mice and men. Nature 2011; 475: 123-128.

16. Cartmell J, Monn JA, Schoepp DD. Attenuation of specific PCP-evoked behaviors by the potent mGlu2/3 receptor agonist, LY379268 and comparison with the atypical antipsychotic, clozapine. Psychopharmacology 2000a; 148: 423-429.

17. Grayson B, Idris NF, Neill JC. Atypical antipsychotics attenuate a sub-chronic PCP-induced cognitive deficit in the novel object recognition task in the rat. Behav Brain Res 2007; 184: 31-38.

18. Horiguchi M, Huang M, Meltzer HY. Interaction of $\mathrm{mGlu}_{2} /{ }_{3}$ agonism with clozapine and lurasidone to restore novel object recognition in subchronic phencyclidine-treated rats. Psychopharmacology (Berl) 2011; 217: 13-24

19. Lyon L, Saksida LM, Bussey TJ. Spontaneous object recognition and its relevance to schizophrenia: a review of findings from pharmacological, genetic, lesion and developmental rodent models. Psychopharmacology (Berl) 2012; 220: 647-672.

20. Meltzer HY, Horiguchi M, Massey BW. The role of serotonin in the NMDA receptor antagonist models of psychosis and cognitive impairment. Psychopharmacology (Berl) 2011; 213: 289-305.

21. Moghaddam B, Adams BW. Reversal of phencyclidine effects by a group II metabotropic glutamate receptor agonist in rats. Science 1998; 281: 1349-1352.

22. Mutlu O, Ulak G, Celikyurt IK, Akar FY, Erden F, Tanyeri P. Effects of olanzapine, sertindole and clozapine on MK-801 induced visual memory deficits in mice. Pharmacol Biochem Behav 2011; 99: 557-565.

23. Rorick-Kehn LM, Johnson BG, Burkey JL, Wright RA, Calligaro DO, Marek GJ et al. Pharmacological and pharmacokinetic properties of a structurally novel, potent, and selective metabotropic glutamate $2 / 3$ receptor agonist: in vitro characterization of agonist (-)-(1R,4S,5S,6S)-4-amino-2-sulfonylbicyclo[3.1.0]-hexane-4,6-dicarboxylic acid (LY404039). J Pharmacol Exp Ther 2007; 321: 308-317.

24. Snigdha S, Idris N, Grayson B, Shahid M, Neill JC. Asenapine improves phencyclidineinduced object recognition deficits in the rat: evidence for engagement of a dopamine D1 receptor mechanism. Psychopharmacology (Berl) 2011; 214: 843-853.

25. Woolley ML, Pemberton DJ, Bate S, Corti C, Jones DN. The mGlu2 but not the mGlu3 receptor mediates the actions of the mGluR2/3 agonist, LY379268, in mouse models predictive of antipsychotic activity. Psychopharmacology (Berl) 2008; 196: 431-440.

26. Neale JH, Bzdega T, Wroblewska B. N-acetylaspartylglutamate: the most abundant peptide neurotransmitter in the mammalian central nervous system. J Neurochem 2000; 75: $443-452$

27. Neale $\mathrm{JH}$. N-acetylaspartylglutamate (NAAG) is an agonist at mGluR3 in vivo and in vitro. $J$ Neurochem 2011; 119: 891-895.

28. Neale JH, Olszewski RT, Zuo D, Janczura KJ, Profaci CP, Lavin KM et al. Advances in understanding the peptide neurotransmitter NAAG and appearance of a new member of the NAAG neuropeptide family. J Neurochem 2011; 118: 490-498.

29. Olszewski RT, Bzdega T, Neale JH. mGluR3 and not mGluR2 receptors mediate the efficacy of NAAG peptidase inhibitor in PCP model of schizophrenia. Schizophr Res 2012; 136: 160-161.

30. Slusher BS, Vornov JJ, Thomas AG, Hurn PD, Harukuni I, Bhardwaj A et al. Selective inhibition of NAALADase, which converts NAAG to glutamate, reduces ischemic brain injury. Nat Med 1999; 5: 1396-1402.

31. Zhong C, Zhao X, Van KC, Bzdega T, Smyth A, Zhou J et al. NAAG peptidase inhibito increases dialysate NAAG and reduces glutamate, aspartate and GABA levels in the dorsal hippocampus following fluid percussion injury in the rat. $J$ Neurochem 2006; 97: 1015-1025.

32. Olszewski RT, Bukhari N, Zhou J, Kozikowski AP, Wroblewski JT, Shamimi-Noori S et al. NAAG peptidase inhibition reduces locomotor activity and some stereotypes in the PCP model of schizophrenia via group II mGluR. J Neurochem 2004; 89: 876-885.

33. Olszewski RT, Wegorzewska MM, Monteiro AC, Krolikowski KA, Zhou J, Kozikowski AP et al. Phencyclidine and dizocilpine induced behaviors reduced by $\mathrm{N}$ acetylaspartylglutamate peptidase inhibition via metabotropic glutamate receptors. Biol psychiatry 2008; 63: 86-91.

34. Cartmell J, Monn JA, Schoepp DD. The metabotropic glutamate 2/3 receptor agonists LY354740 and LY379268 selectively attenuate phencyclidine versus $d$-amphetamine motor behaviors in rats. J Pharmacol Exp Ther 1999; 291: 161-170.

35. Cartmell J, Monn JA, Schoepp DD. The mGlu(2/3) receptor agonist LY379268 selectively blocks amphetamine ambulations and rearing. Eur J Pharmacol 2000b; 400: 221-224.

36. Fell MJ, Svensson KA, Johnson BG, Schoepp DD. Evidence for the role of metabotropic glutamate (mGlu)2 not mGlu3 receptors in the preclinical antipsychotic pharmacology of the mGlu2/3 receptor agonist (-)-(1R,4S,5S,6S)-4-amino-2-sulfonylbicyclo[3.1.0]hexane4,6-dicarboxylic acid (LY404039). J Pharmacol Exp Ther 2008; 326: 209-217. 
37. Jones CA, Brown AM, Auer DP, Fone KC. The mGluR2/3 agonist LY379268 reverses post-weaning social isolation-induced recognition memory deficits in the rat. Psychopharmacology (Berl) 2010; 214: 269-283.

38. Krystal JH, Abi-Saab W, Perry E, D'Souza DC, Liu N, Gueorguieva R et al. Preliminary evidence of attenuation of the disruptive effects of the NMDA glutamate receptor antagonist, ketamine, on working memory by pretreatment with the group II metabotropic glutamate receptor agonist, LY354740, in healthy human subjects. Psychopharmacology (Berl) 2005; 179: 303-309.

39. Profaci CP, Krolikowski KA, Olszewski RT, Neale JH. Group II mGluR agonist LY354740 and NAAG peptidase inhibitor effects on prepulse inhibition in PCP and D-amphetamine models of schizophrenia. Psychopharmacology (Berl) 2011; 216: 235-243.

40. Schlumberger $C$, Schäfer D, Barberi $C$, Morè L, Nagel J, Pietraszek $M$ et al. Effects of a metabotropic glutamate receptor group II agonist LY354740 in animal models of positive schizophrenia symptoms and cognition. Behav Pharmacol 2009; 20: 56-66.

41. Vales K, Svoboda J, Benkovicova K, Bubenikova-Valesova V, Stuchlik A. The difference in effect of mGlu2/3 and mGlu5 receptor agonists on cognitive impairment induced by MK801. Eur J Pharmacol 2010; 639: 91-98.

42. Patil ST, Zhang L, Martenyi F, Lowe SL, Jackson KA, Andreev BV et al. Activation of $\mathrm{mGlu2/3}$ receptors as a new approach to treat schizophrenia: a randomized Phase 2 clinical trial. Nat Med 2007; 13: 1102-1107.

43. Kinon BJ, Zhang L, Millen BA, Osuntokun OO, Williams JE, Kollack-Walker S et al. A multicenter, inpatient, phase 2, double-blind, placebo-controlled dose-ranging study of LY2140023 monohydrate in patients with DSM-IV schizophrenia. J Clin Psychopharmacol 2011; 31: 349-355

44. Monn JA, Valli MJ, Massey SM, Hansen MM, Kress TJ, Wepsiec JP et al. Synthesis, pharmacological characterization, and molecular modeling of heterobicyclic amino acids related to (+)-2-aminobicyclo[3.1.0] hexane-2,6-dicarboxylic acid (LY354740): identification of two new potent, selective, and systemically active agonists for group II metabotropic glutamate receptors. J Med Chem 1999; 42: 1027-1040.

45. Neale JH, Olszewski RT, Gehl LM, Wroblewska B, Bzdega T. The neurotransmitter $N$ acetylaspartylglutamate in models of pain, ALS, diabetic neuropathy, CNS injury and schizophrenia. Trends Pharmacol Sci 2005; 26: 477-484.

46. Thomas AG, Wozniak KM, Tsukamoto T, Calvin D, Wu Y, Rojas $C$ et al. Glutamate carboxypeptidase II (NAALADase) inhibition as a novel therapeutic strategy. Adv Exp Med Biol 2006; 576: 327-337; discussion 361-363.

47. Higgins GA, Ballard TM, Kew JN, Richards JG, Kemp JA, Adam G et al. Pharmacological manipulation of mGlu2 receptors influences cognitive performance in the rodent. Neuropharmacology 2004; 46: 907-917.

48. Horiguchi M, Huang M, Meltzer HY. The role of 5-hydroxytryptamine 7 receptors in the phencyclidine-induced novel object recognition deficit in rats. J Pharmacol Exp Ther 2011; 338: $605-614$

49. Watson DJ, Marsden CA, Millan MJ, Fone KC. Blockade of dopamine D3 but not D2 receptors reverses the novel object discrimination impairment produced by post-weaning social isolation: implications for schizophrenia and its treatment. Int $J$ Neuropsychopharmacol 2011; 18: 1-14

50. Bacich DJ, Ramadan E, O'Keefe DS, Bukhari N, Wegorzewska I, Ojeifo O et al. Deletion of the glutamate carboxypeptidase II gene in mice reveals a second enzyme activity that hydrolyzes $\mathrm{N}$-acetylaspartylglutamate. J Neurochem 2002; 83: 20-29.

51. Zhou J, Neale JH, Pomper MG, Kozikowski AP. NAAG peptidase inhibitors and their potential for diagnosis and therapy. Nat Rev Drug Discov 2005; 4: 1015-1026.

52. Yamamoto T, Hirasawa S, Wroblewska B, Grajkowska E, Zhou J, Kozikowski A et al. Antinociceptive effects of $\mathrm{N}$-acetylaspartylglutamate (NAAG) peptidase inhibitors ZJ-11, $\mathrm{ZJ}-17$ and ZJ-43 in the rat formalin test and in the rat neuropathic pain model. Eur J Neurosci 2004; 20: 483-494.

53. Jackson PF, Slusher BS. Design of NAALADase inhibitors: a novel neuroprotective strategy. Curr Med Chem 2001; 8: 949-957.

54. Tsukamoto T, Wozniak KM, Slusher BS. Progress in the discovery and development of glutamate carboxypeptidase II inhibitors. Drug Discov Today 2007; 12: 767-776.

55. Kingston AE, Ornstein PL, Wright RA, Johnson BG, Mayne NG, Burnett JP et al. LY341495 is a nanomolar potent and selective antagonist of group II metabotropic glutamate receptors. Neuropharmacology 1998; 37: 1-12.

56. Nilsson M, Hansson S, Carlsson A, Carlsson ML. Differential effects of the N-methyl-daspartate receptor antagonist MK-801 on different stages of object recognition memory in mice. Neuroscience 2007; 149: 123-130.

57. Yamamoto T, Saito O, Aoe T, Bartolozzi A, Sarva J, Zhou J et al. Local administration of $\mathrm{N}$-acetylaspartylglutamate (NAAG) peptidase inhibitors is analgesic in peripheral pain in rats. Eur J Neurosci 2007; 25: 147-158.

58. Sartorius LJ, Weinberger DR, Hyde TM, Harrison PJ, Kleinman JE, Lipska BK. Expression of a GRM3 splice variant is increased in the dorsolateral prefrontal cortex of individuals carrying a schizophrenia risk SNP. Neuropsychopharmacology 2008; 33: 2626-2634.

59. Ghose S, Gleason KA, Potts BW, Lewis-Amezcua K, Tamminga CA. Differential expression of metabotropic glutamate receptors 2 and 3 in schizophrenia: a mechanism for antipsychotic drug action? Am J Psychiatry 2009b; 166: 812-820.

60. Ghose S, Chin R, Gallegos A, Roberts R, Coyle J, Tamminga C. Localization of NAAGrelated gene expression deficits to the anterior hippocampus in schizophrenia. Schizophr Res 2009a; 111: 131-137.

61. Corti C, Battaglia G, Molinaro G, Riozzi B, Pittaluga A, Corsi M et al. The use of knockout mice unravels distinct roles for mGlu2 and mGlu3 metabotropic glutamate receptors in mechanisms of neurodegeneration/neuroprotection. J Neurosci 2007; 27 8297-8308.

62. Galici R, Jones CK, Hemstapat K, Nong Y, Echemendia NG, Williams LC et al. Biphenylindanone $\mathrm{A}$, a positive allosteric modulator of the metabotropic glutamate receptor subtype 2, has antipsychotic- and anxiolytic-like effects in mice. J Pharmacol Exp Ther 2006; 318: 173-185.

63. Zhong C, Zhao X, Sarva J, Kozikowski A, Neale JH, Lyeth BG. NAAG peptidase inhibitor reduces acute neuronal degeneration and astrocyte damage following lateral fluid percussion TBI in rats. J Neurotrauma 2005; 22: 266-276.

64. Aultman JM, Moghaddam B. Distinct contributions of glutamate and dopamine receptors to temporal aspects of rodent working memory using a clinically relevant task. Psychopharmacology (Berl) 2001; 153: 353-364.

65. Shimazaki T, Kaku A, Chaki S. Blockade of the metabotropic glutamate 2/3 receptors enhances social memory via the AMPA receptor in rats. Eur J Pharmacol 2007; 575: 94-97.

66. Linden AM, Johnson BG, Trokovic N, Korpi ER, Schoepp DD. Use of MGLUR2 and MGLUR3 knockout mice to explore in vivo receptor specificity of the MGLUR2/3 selective antagonist LY341495. Neuropharmacology 2009; 57: 172-182.

67. Baune BT, Suslow T, Beœte C, Birosova E, Domschke K, Sehlmeyer C et al. Association between genetic variants of the metabotropic glutamate receptor 3 (GRM3) and cognitive set shifting in healthy individuals. Genes Brain Behav 2010; 9: 459-466.

68. Egan MF, Straub RE, Goldberg TE, Yakub I, Callicott JH, Hariri AR et al. Variation in GRM3 affects cognition, prefrontal glutamate, and risk for schizophrenia. Proc Natl Acad Sci U SA 2004; 101: 12604-12609.

69. Tan HY, Chen Q, Sust S, Buckholtz JW, Meyers JD, Egan MF et al. Epistasis between catechol-O-methyltransferase and type II metabotropic glutamate receptor 3 genes on working memory brain function. Proc Natl Acad Sci U S A 2007; 104 12536-12541.

(c)

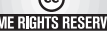

Derivative Works 3.0 Unported License. To view a copy of this license, visit http://creativecommons.org/licenses/by-nc-nd/3.0/ 